\title{
TRADE FAIR FEE AS A SOURCE OF INCOME FOR THE BUDGETS OF MUNICIPALITIES IN POLAND ON SELECTED EXAMPLES
}

\section{Cezary SZYDŁOWSKI ${ }^{1}$}

Abstract

\begin{abstract}
The public finance system in force in Poland provides for a trade fair fee (Polish - „opłata targowa”) as part of municipalities' own revenues. The trade fair fee is collected from persons selling at marketplaces located in the municipality. It constitutes own income for the commune's budget and is an archaic form of public tribute. According to the legal regulations in force in Poland, communes may waive the collection of the exhibition fee, however, there are still many communes collecting it. The assessment of income to the commune budget from the trade fair fee was carried out on the basis of a survey of income to the budget of selected 10 coastal communes in Pomorskie Voivodeship. The selection of coastal municipalities was determined by their specificity in terms of retail trade on markets and squares. This is because the holiday season attracts many tourists and entrepreneurs who sell the goods they offer in the mode of direct retail trade carried out on local markets, streets or squares (often located near the entrance to local beaches). The analysis of income from the fair fee was carried out on the basis of reports on the implementation of the budgets of communes and reports on the income of communes $\mathrm{Rb}-27 \mathrm{~s}$ published by commune authorities on the pages of the Public Information Bulletin of a given local government unit. Verification of the revenue of the selected 10 municipalities from the fair fee for 2016-2019 revealed a very low share of the fair fee in the total revenue to the municipalities' budgets (maximum 1.60\% for the Łeba municipality in 2016). Moreover, the communes incur significant costs related to the collection of the trade fair fee, which are connected with the payment of commissions on the collected amounts up to $25 \%$ of the total income from the fee.

The results of the research indicate that it would be reasonable for the authorities of the analysed communes to consider abolishing the trade fair fee in their area, as the revenue is small compared to the costs incurred.

The liquidation of the market fee may attract more traders and improve the image of the commune as a facilitator of business activities involving trade in marketplaces.
\end{abstract}

JEL classification: $\mathrm{H71}$, H83

Keywords: audit, budget revenues, local tax, public finance, local government, trade fair fee 


\section{INTRODUCTION}

The legal solutions adopted in Poland have granted municipalities the right to establish and collect local taxes and fees. Communes constitute a basic unit of local administration, which performs various tasks for the benefit of the local community. The system created for financing local government activities enables communes to collect appropriate public levies, which constitute sources of their own income. This includes a market fee, which is collected by the commune from legal and natural persons selling goods at marketplaces.

The trade fair fee is a very outdated form of public tribute imposed by municipalities. It was one of the sources of income in Poland during the 30 years of the local government's operation, starting from the beginning of the economic transformation in the early 1990s, when commercial activity was one of the basic manifestations of Polish entrepreneurship and focused on local marketplaces of particular towns and villages. The economic development of Poland resulted in very large structural changes in trade activity, mainly through limiting the scale of trade in marketplaces in favour of large-format stores. This process has been progressing dynamically in Poland since the turn of the 20th and 21st century. Through their expansion on the retail market, large stores of international retail chains have taken over a large share of customers who had previously purchased goods in smaller stores and markets. The expansion of retail chains has contributed to a change in the structure of trade, which has resulted in a decrease in the number of consumers willing to make purchases at local markets (Maciejewski, 2017). The reduction in the role of marketplaces, which have been replaced to a large extent by large-format shops, has resulted in a decrease in the revenue of municipalities from the market fee. Despite changes in the Polish trade structure and a limited number of sellers, communes still charge the market fee. The legal regulations allow the municipal authorities to abolish the market fee, which some local governments have implemented, e.g. the city of Gdańsk (Resolution No $\mathrm{XV} / 398 / 15,2015)$. Therefore, the establishment of the level of revenues to the municipalities' budget from the trade fair fee is an interesting research area. Additionally, the share of revenues from the trade fair fee in the total income of the municipality should also be determined. The tendency to decrease the total number of people selling at marketplaces means that the income to the commune budget is decreasing. Apart from the budgetary effects, the decrease in revenues from the market fee also indicates a decrease in the number of sellers and traders offering their goods at local community marketplaces.

In view of the above, the purpose of the research for the purposes of this publication was to obtain an answer to the question of what the municipalities' income from the trade fair fee is and what is its share in the municipalities' total income. In addition, the study of municipalities' revenues in the selected scope is an important research area in the area of public finance. However, the results of the conducted analysis may constitute interesting material for those interested in local taxes and fees in Poland.

The assessment of the municipalities' revenues from the local charge was decided on the basis of the financial reports on the implementation of the municipality budget for the year. The reports contain reliable financial data on the level of revenue to the municipalities' budgets from particular taxes and local fees for a given year. The analysis of income from the fair fee was carried out on the basis of 10 coastal municipalities from Pomorskie Voivodeship in Poland (urban and rural municipalities). The choice of coastal municipalities was due to the fact that during the holiday season the number of merchants selling goods to tourists spending their holidays in their area increases locally. The holiday period generates in coastal municipalities a large increase in the number of merchants at local marketplaces, which should contribute to significant revenues from the fair fee, which may justify the need to maintain them by local authorities. The structure of this publication includes: a presentation of the research method, the literature review, research results and conclusions and the summary.

\section{RESEARCH METHODS}

The article uses a case study, an analytical method, an inference method, a method of examining source documents and a literature review as research methods. The analysis of income of individual communes was carried out on the basis of data contained in reports on the implementation of commune budgets in a given year (for the years 2016 -2019) and reports Rb-27s on the income obtained by municipalities in the evaluated year, published in the Public Information Bulletins (on the websites) of the analysed municipalities. 
The study covered the evaluation of total revenue to the commune budget and commune revenues on account of the fair fee in 10 selected coastal communes of Pomorskie Voivodeship in Poland, 7 municipalities (i.e. Gdynia, Jastarnia, Łeba, the City of Puck, Sopot, the City of Ustka, Władysławowo) and 3 rural municipalities (i.e. Krokowa, Stegna and Ustka Municipalities). The choice of the communes was determined by their location and availability of data for the survey. The surveyed time horizon covered the years 2016-2019. The first stage of the survey was the assessment of the overall income to the budgets of individual communes, then the share of receipts from the trade fair fee in the overall income of the communes was established. The analyses were the basis for a general assessment of the significance of revenues from the trade fair fee in the revenues of the budgets of the 10 municipalities under analysis. For the purposes of the analysis, nominal amounts of revenues to the budgets of individual 10 communes in 2016-2019 were taken into account.

\section{LITERATURE REVIEW}

The purpose of this publication was to assess the level of communes' income from the fair fee and their share in the total income of communes.

Municipal governments in Poland finance their tasks from taxes and local fees. Ensuring an adequate system of financing the activities of communes is the basis for the independence of communal authorities in making decisions concerning the local community. No undertaking by a commune authority is possible without an adequate system of financing. The municipalities have their own budget, in the form of public levies and funds provided by the State from the central budget. Caring for the development of the municipality requires effective action to increase budget revenues. Increase of income to the commune budget translates into the possibility to carry out investments for the local community that improve the standard of living of the inhabitants and increase their investment or tourist attractiveness depending on the specificity of the municipality (Bahl \& Linn, 1992).

Local government in Poland at the commune level performs most of the tasks that affect the life of each member of the local community. The realization of these tasks is possible only with an appropriate system of their financing, mainly by establishing a system of local taxes.
Therefore, the Polish system of public finance defines a detailed catalogue of public levies that can be collected by particular local government units, including communes (Owsiak, 2002, pp. 126-128). The catalogue of public levies belonging to self-governments constituting own revenue is defined in the relevant provisions of Polish law (Law, 2003). In addition, Polish specific legislation has defined a catalogue of local taxes and charges that may be collected by municipalities as own revenue (Law, 1991). The need to carry out the tasks assigned to them requires the public authorities to ensure a level of government revenue adequate to expected expenditure. Financing of local government tasks from local taxes is a universal system solution applicable in many democratic countries around the world, including the United States of America (Stiglitz \& Rosengard, 2015, pp. 832-833). It is worth emphasizing that the conducted analyses concerning the tax systems of individual European Union countries prove that local taxes function in many European countries, which is reflected in reports in this respect (Taxation Trends, 2019).

Appropriate organisation of the system of collecting public levies by local authorities is important for efficient execution of particular tasks financed from the commune budget. Providing public services to the commune inhabitants generates costs, which are financed with the income obtained for the commune budget (Bird, 2010). Financial management of the commune should be focused on obtaining the highest possible income in order to be able to carry out its mission and balance the budget of a given local government unit. Therefore, the budgetary policy of commune authorities should focus on maximising revenues, as stable finances constitute a pillar for efficient operation of each commune (Freire \& Garzón, 2014).

Stabilising the municipal budget by balancing expenditure and revenue requires constant monitoring of revenue from individual taxes and local charges. It should also be remembered that raising funds for the budget should not generate significant costs of their collection for the commune. The cost of obtaining a public tribute, which is not commensurate with the amount of the collected tax or local charge, in practice means low efficiency of its collection by the commune. The above situation may occur when the collection of a given public tribute by the municipality requires payment of remuneration to a company or an individual for performing such an activity. In Poland, this situation concerns a number of taxes and local fees for collection of which a commission is set as a 
percentage of the value of the public levy collected from the taxpayer.

In addition to revenue planning, the process of managing public finances of municipalities also requires an appropriate system of control over them. The process of controlling revenues generated by the municipality from individual taxes and local fees is supported by financial audits carried out by external or internal auditors (Copley, 1991). The ongoing and independent assessment of income to the municipal budget may also be commissioned by the municipal authorities to specialised organisational units, e.g. internal control or financial units. An internal audit, which examines the areas covered by the audit task, can be a useful tool for the municipality's management to assess budget revenues (Spencer Pickett, 2010). In addition, the municipalities should periodically carry out a financial audit in order to obtain objective information on the level of revenue to the municipalities' budget. The financial audit is a useful tool used by the municipalities to assess the financial economy.

The level of income to the budget of individual municipalities depends on many factors. The main factor influencing the budget revenues of communes is the social and economic development, the condition of technical infrastructure and the effectiveness of local authorities in collecting the due tributes (Podstawka, p. 112). The amount of income from local taxes also depends, among other things, on their location, natural resources, demography, economic activity, etc. Communes located in areas attractive for tourists attract mainly investments related to services serving tourists (accommodation, bars and restaurants, etc.). Moreover, in the areas of tourist communes during the holiday season, the share of retail trade increases significantly, which very often takes place outside permanent commercial outlets (shops) mainly in local markets and outside them. The holiday season in coastal municipalities contributes to a seasonal increase in the number of businesses operating in the area of these municipalities. A significant part of business entities operating in tourist communes during the summer season is not permanently connected with the commune where they conduct their seasonal business activity. This means that potentially the holiday season contributes to the increase of revenues of coastal communes from taxes and local charges.

The legal solutions in force in Poland make it possible for local governments to collect public levies in the form of taxes and local fees. This fee is of the nature of a compulsory monetary benefit collected by municipal authorities for public services (Parlińska, 2010, p. 310).

The fair fee is collected from persons offering goods at the marketplaces in accordance with the organisational solutions adopted in the given commune. According to the Act, a marketplace is any place where the sale of goods is carried out. (Law, 1991, art. 15). The fair fee is a form of payment by the sellers for the public service, which is the possibility of conducting sales in a specific space belonging to the municipality (Kwaśniewski \& Wantoch-Rekowski, pp. 67-85). This means that the fees are collected from the sellers both on and off the designated communal marketplaces. In the case of places attractive for tourists located in the area of coastal municipalities, sales are very often made outside the marketplaces. Many sellers offer their goods in places located on main roads (pavements and street and roadsides) leading to entrances to beaches and places attractive for tourists or recreation. It should be emphasized that the trade fair fee is collected regardless of additional charges related to the use of the trade fair facilities and for other services provided by the trade fair manager (Law, 1991, art. 15).

The amount of the exhibition fee and the rules of collection shall be adopted by the competent Councils of Cities or Commune Councils, which have the right to determine the amount of the exhibition fee. The legislator in order to limit the amount of the trade fair fee charged, granted the Minister of Finance the power to determine the maximum rates of the trade fair fee for each day of trade which may be set by the municipality in a given year. The maximum rates of the daily exhibition fee set by the Minister of Finance for a given year in 2016-2019 are presented in Table 1.

Table 1: Maximum daily rates of the trade fair fee in 2016-2019

\begin{tabular}{|c|c|c|c|c|c|c|}
\hline \multirow{2}{*}{ Name } & \multicolumn{2}{c|}{ Maximum daily rate of trade fair fee in a given year in PLN } & \multicolumn{3}{c|}{ Rate changes in \% (year-on-year) } \\
\hline Year & 2016 & 2017 & 2018 & 2019 & $2017 / 2016$ & $2018 / 2017$ \\
\hline Fair fee in PLN & 758,47 & 751,65 & 765,94 & 778,2 & $-0,90 \%$ & $1,90 \%$ \\
\hline
\end{tabular}

Source: Own study based on the announcements of the Minister of Finance and the Minister of Finance and Development on the upper limits of specific taxes and local fees in the years 2016, 2017, 2018, 2019 (M.P. from 2015, item 735, M.P. from 2016, item 779, M.P. from 2017, p item 800, M.P. from 2018 item 745). 
The maximum daily exhibition fee rates for a given year indicate that its amount was reduced by $0.9 \%$ in 2017 as compared to 2016, while in the following years (2018 and 2019) it increased from $1.60 \%$ (2018) to $1.60 \%$ (2019) as compared to previous years.

When determining the amount of the fair fee, individual communes depend on various factors, such as e.g. the seasons, e.g. the Resolution of the Gdynia City Council, which specified higher fees in the summer season (Resolution No. XIII/250/15, 2015). Usually, the fair fee is collected by those appointed by the municipality, who receive remuneration for these activities representing a certain percentage of the amount collected from the seller. The collection of the trade fair fee is carried out by the municipalities and the income from it constitutes income for their budgets. In view of the above, it should be concluded that the trade fair fee is one of the revenue items for the commune's budget, the cost of collection of which may be inadequate to the revenue generated on this account. This means that the possible abandonment of its collection may not cause significant loss of revenue to the commune's budget.

\section{ANALYSIS OF INCOME TO THE MUNICIPALITIES' BUDGET FROM THE TRADE FAIR FEE}

The assessment of income to the municipalities' budgets from the trade fair fee begins with an analysis of its share in the total income to the municipality's budget. Table 2 presents a statement containing the share of income from the fair fee in the total income to the budgets of the 10 analysed communes of Pomorskie Voivodeship in Poland.

The income statement presented in Table 2 shows that the trade fair fee charged to vendors in particular communes in 2016-2019 constituted a small percentage share in total budget revenues. The highest share of the trade fair fee in the commune's income on this account was recorded by the Łeba commune in 2016 (the share was $1.60 \%$ of total budget income, nominal income of PLN $449,456)$. The lowest share of the exhibition fee in the income to the commune budget was recorded in Gdynia (share of $0.01 \%$ in 2018 and 2019, nominal income, in 2018 amounted to - PLN 217,218 and in 2019 - PLN 142,100).

The highest annual share of the fair fee in the income to the commune budget in 2016-2019 was obtained by the Łeba commune (1.60\% in 2016, $1.50 \%$ in 2017, $1.33 \%$ in 2018 and $1.29 \%$ in 2019). The lowest share in revenues to the commune budget from the fair fee in the examined period had Gdynia (0.02\% in 2016-2017 and 0.01\% in two subsequent years 2018-2019).

It should be noted, however, that in the surveyed period, the city of Gdynia achieved a relatively high level of income to the total budget in comparison with other urban and rural communes covered by the analysis. Similarly, very low income to the municipal budget from the fair fee was established in Sopot (income at the level of $0.05 \%$ in $2016-2018$ and $0.04 \%$ of income to the total budget in 2019).

The second commune among the surveyed, which in 2016-2019 received income to the budget from the fair fee at a level exceeding $1 \%$ was Jastarnia commune $(1.33 \%)$ in 2016, $1.39 \%$

in 2017, 1.32\% in 2018 and $1.11 \%$ in 2019 of total budget revenue). Of the 3 rural communes covered by the survey, the lowest level of total income to the budget from the fair fee was obtained by the rural commune of Ustka $(0.15 \%$ in $2016,0.17 \%$ in $2017,0.20 \%$ in 2018 and $0.18 \%$ in 2019 of total revenues to the budget). The list presented in Table 2 shows that the trade fair fee constitutes a small, even fractional share in total budget revenues in the communes under analysis. On the basis of the data set for the years 2016-2019, the following ranges of the share of the exhibition fee in total budget revenues in communes can be determined:

1) in 2016, revenues from the fair fee ranged from $0.02 \%$ share in total revenues (city

of Gdynia) to $1.60 \%$ share (city of Łeba),

2) in 2017, revenues from the fair fee ranged from $0.02 \%$ share in total revenues (city

of Gdynia) to $1.50 \%$ share (city of Łeba),

3 ) in 2018, income from the fair fee ranged from $0.01 \%$ share in total income (city of Gdynia) to $1.39 \%$ share (city of Łeba),

$4)$ in 2019, income from the fair fee ranged from $0.01 \%$ of total income (city of Gdynia)

to $1.29 \%$ (city of Łeba).

Generally speaking, the results of the analysis of the general share of revenues to the budgets of municipalities from the trade fair fee prove that in 2016-2019 there was a downward trend in revenues from the trade fair fee. This 
Table 2: Share of revenues from the trade fair fee in the total revenues of the analyzed municipalities in 2016-2019

\begin{tabular}{|c|c|c|c|c|c|c|c|c|c|c|c|c|c|}
\hline \multirow[t]{2}{*}{$\begin{array}{l}\text { Name of the } \\
\text { municipality }\end{array}$} & \multirow[t]{2}{*}{$\begin{array}{l}\text { Municipal } \\
\text { status }\end{array}$} & \multicolumn{4}{|c|}{$\begin{array}{l}\text { Total budget revenues in the years } \\
\text { in PLN }\end{array}$} & \multicolumn{4}{|c|}{$\begin{array}{l}\text { Revenue from the trade fair fee in } \\
\qquad 2016-2019\end{array}$} & \multicolumn{4}{|c|}{$\begin{array}{l}\text { Share of the fair fee in the total } \\
\text { income of the municipality in } 2016 \\
-2019 \text { in \% }\end{array}$} \\
\hline & & 2016 & 2017 & 2018 & 2019 & 2016 & 2017 & 2018 & 2019 & 2016 & 2017 & 2018 & 2019 \\
\hline Gdynia & urban & $\begin{array}{c}1361 \\
861 \\
892\end{array}$ & $\begin{array}{c}1409 \\
667 \\
667\end{array}$ & $\begin{array}{c}1605 \\
977 \\
090\end{array}$ & $\begin{array}{c}1803 \\
290 \\
009\end{array}$ & $\begin{array}{l}246 \\
231\end{array}$ & $\begin{array}{l}221 \\
724\end{array}$ & $\begin{array}{l}217 \\
218\end{array}$ & $\begin{array}{l}142 \\
100\end{array}$ & $0,02 \%$ & $0,02 \%$ & $0,01 \%$ & $0,01 \%$ \\
\hline Jastarnia & urban & $\begin{array}{c}25001 \\
066\end{array}$ & $\begin{array}{c}26397 \\
078\end{array}$ & $\begin{array}{c}27655 \\
390\end{array}$ & $\begin{array}{c}33224 \\
821\end{array}$ & $\begin{array}{l}333 \\
107\end{array}$ & $\begin{array}{l}367 \\
540\end{array}$ & $\begin{array}{l}364 \\
941\end{array}$ & $\begin{array}{l}367 \\
335\end{array}$ & $1,33 \%$ & $1,39 \%$ & $1,32 \%$ & $1,11 \%$ \\
\hline Łeba & urban & $\begin{array}{c}28033 \\
893\end{array}$ & $\begin{array}{c}29165 \\
381\end{array}$ & $\begin{array}{c}29738 \\
755\end{array}$ & $\begin{array}{c}30612 \\
119\end{array}$ & $\begin{array}{l}449 \\
456\end{array}$ & $\begin{array}{l}436 \\
812\end{array}$ & $\begin{array}{l}411 \\
651\end{array}$ & $\begin{array}{l}395 \\
519\end{array}$ & $1,60 \%$ & $1,50 \%$ & $1,38 \%$ & $1,29 \%$ \\
\hline City of Puck & urban & $\begin{array}{c}50606 \\
379\end{array}$ & $\begin{array}{c}55524 \\
472\end{array}$ & $\begin{array}{c}61153 \\
228\end{array}$ & $\begin{array}{c}64982 \\
579\end{array}$ & $\begin{array}{l}177 \\
748\end{array}$ & $\begin{array}{l}122 \\
169\end{array}$ & 87071 & 41604 & $0,35 \%$ & $0,22 \%$ & $0,14 \%$ & $0,06 \%$ \\
\hline Sopot & urban & $\begin{array}{l}299 \\
516 \\
562\end{array}$ & $\begin{array}{l}294 \\
965 \\
739\end{array}$ & $\begin{array}{l}329 \\
271 \\
246\end{array}$ & $\begin{array}{l}380 \\
025 \\
764\end{array}$ & $\begin{array}{l}145 \\
258\end{array}$ & $\begin{array}{l}146 \\
773\end{array}$ & $\begin{array}{l}157 \\
494\end{array}$ & $\begin{array}{l}149 \\
993\end{array}$ & $0,05 \%$ & $0,05 \%$ & $0,05 \%$ & $0,04 \%$ \\
\hline Miasto Ustka & urban & $\begin{array}{c}69993 \\
683\end{array}$ & $\begin{array}{c}82652 \\
109\end{array}$ & $\begin{array}{c}92562 \\
661\end{array}$ & $\begin{array}{c}86641 \\
187\end{array}$ & $\begin{array}{l}255 \\
296\end{array}$ & $\begin{array}{l}210 \\
841\end{array}$ & $\begin{array}{l}166 \\
920\end{array}$ & $\begin{array}{l}105 \\
618\end{array}$ & $0,36 \%$ & $0,26 \%$ & $0,18 \%$ & $0,12 \%$ \\
\hline Władysławowo & urban & $\begin{array}{c}81167 \\
785\end{array}$ & $\begin{array}{c}90660 \\
191\end{array}$ & $\begin{array}{c}98907 \\
833\end{array}$ & $\begin{array}{l}107 \\
860 \\
328\end{array}$ & $\begin{array}{l}692 \\
743\end{array}$ & $\begin{array}{l}638 \\
706\end{array}$ & $\begin{array}{l}630 \\
924\end{array}$ & $\begin{array}{l}787 \\
504\end{array}$ & $0,85 \%$ & $0,70 \%$ & $0,64 \%$ & $0,73 \%$ \\
\hline Krokowa & rural & $\begin{array}{c}58137 \\
528\end{array}$ & $\begin{array}{c}60270 \\
623\end{array}$ & $\begin{array}{c}69812 \\
054\end{array}$ & $\begin{array}{c}68849 \\
324\end{array}$ & $\begin{array}{l}162 \\
751\end{array}$ & $\begin{array}{l}169 \\
337\end{array}$ & $\begin{array}{l}155 \\
180\end{array}$ & $\begin{array}{l}160 \\
429\end{array}$ & $0,28 \%$ & $0,28 \%$ & $0,22 \%$ & $0,23 \%$ \\
\hline Stegna & rural & $\begin{array}{c}43427 \\
860\end{array}$ & $\begin{array}{c}50272 \\
751\end{array}$ & $\begin{array}{c}60762 \\
642\end{array}$ & $\begin{array}{c}52626 \\
961\end{array}$ & $\begin{array}{l}150 \\
476\end{array}$ & $\begin{array}{l}264 \\
113\end{array}$ & $\begin{array}{l}280 \\
977\end{array}$ & $\begin{array}{l}297 \\
757\end{array}$ & $0,35 \%$ & $0,53 \%$ & $0,46 \%$ & $0,57 \%$ \\
\hline $\begin{array}{l}\text { Communes of } \\
\text { Ustka }\end{array}$ & rural & $\begin{array}{c}48646 \\
225\end{array}$ & $\begin{array}{c}47852 \\
861\end{array}$ & $\begin{array}{c}51153 \\
840\end{array}$ & $\begin{array}{c}61004 \\
812\end{array}$ & 75370 & 81809 & 99923 & $\begin{array}{l}112 \\
258\end{array}$ & $0,15 \%$ & $0,17 \%$ & $0,20 \%$ & $0,18 \%$ \\
\hline
\end{tabular}

Source: Own study based on reports Rb-27s and reports on the implementation of the commune budget for 2016-2019 published in Public Information Bulletins by local governments

means that despite the insignificant share of the fee in the revenues in question, communes may potentially obtain less and less revenue to the budget with each year of this tribute. Such a situation may indicate that municipalities in Poland which would undertake in the future the decision to eliminate the trade fair fee as an own income to the municipality budget would not incur significant budget losses. However, one should be aware that every amount of income to the commune budget, regardless of the form of public tribute, supports the financing of planned expenses related to the performance of commune tasks, for example in the area of providing public services or making investments. Potential liquidation of the fair fee by the municipal authorities may result in problems in the coming years in ensuring the financial stability of a given local government unit. A serious decline in the economic development of countries around the world may contribute to it due to the economic crisis resulting from the global epidemic in 2020. Preliminary forecasts for global economic development clearly indicate a serious risk of a global economic crisis. This is evidenced by reports prepared, among others, by the International Monetary Fund (World Economic Outlook, IMF, April 2020). The economic crisis caused by the epidemic will contribute to large drops in income to the budgets of municipalities, and therefore it seems that it would be inappropriate for local authorities to give up collecting the fair fee. A separate issue is the high probability of low income from the trade fair fee for coastal municipalities. Planning of budget revenues for the following year is based on the financial results achieved in the previous year, increased by the projected price indices of consumer goods and services in the following year. Currently, the municipalities' forecasting of income levels is very difficult due to the progressing global economic crisis. The effects of the ongoing crisis caused by the epidemic are already being felt by global economies such as the United States, as evidenced by data on "The Consumer Price Index for All Urban Consumers declined 0.4 percent in march on a seasonally adjusted basis, the largest monthly decline 
Table 3: Price indices of consumer goods and services in Poland in years 2016-2019

\begin{tabular}{|c|c|c|c|c|}
\hline \multicolumn{5}{|c|}{ Yearly price indices of consumer goods and services in Poland in years 2016-2019 } \\
(Price index previous year = 100)
\end{tabular}

Source: https://stat.gov.pl/en/topics/prices-trade/price-indices/price-indices-of-consumer-goods-and-services/yearlyprice-indices-of-consumer-goods-and-services-from-1950/

since January 2015" (CPI-U, 2020).

Summary of the evolution of the indicator Price indices of consumer goods and services in Poland) for the period 2016-2019 is shown in Table 3.

The next stage of the analysis of income from the fair fee is the assessment of the nominal level of decrease or income to the municipalities' budget from the fee in question, which is presented in Table 4.

The analysis of the nominal revenues of municipalities from the trade fair fee in 2016-2019 shows that the highest annual decrease was in 2019 in Puck (52\% decrease compared to 2018). The City of Puck also recorded decreases in the remaining years covered by the assessment on an annual basis (a 17\% decrease in 2017 compared to 2016 and a 29\% decrease in 2018 compared to 2017). This clearly indicates that the City of Puck, when collecting a trade fair fee from sellers at its marketplaces, did not achieve the planned increase in budget revenues in a given year. The predicted difficult economic situation with a nominal decrease in income from the analysed tribute may result in difficulties in ensuring that the communes fulfill their tasks in this case, it may concern the Puck commune. Other communes which have recorded significant nominal drops in revenue from the fair fee on an annual basis were the cities of Ustka (the highest nominal drop in revenue from the fee by $37 \%$ in 2019 compared to 2018) and Gdynia (the highest nominal drop in revenue from the fee by $35 \%$ in 2019 compared to 2018). In the period under examination, the cities of Ustka and Gdynia recorded annual decreases in revenue to the budget from the fair fee.

Out of the 10 surveyed communes, only two - Stegna and the rural commune of Ustka - recorded annual increases in revenue to the budget from the trade fair fee. The highest $76 \%$ annual increase in nominal income to the budget from the trade fair fee was recorded in 2017 in Stegna municipality (compared to the income in 2016).

Table 5 presents a general overview of the dynamics of income from the trade fair fee in the surveyed communes in 2016-2019 in relation to the base year 2016.

Table 4: Changes in income from the trade fair fee in the examined communes of the Pomeranian Province in Poland in 2016-2019

\begin{tabular}{|c|c|c|c|c|c|c|c|c|c|c|c|}
\hline \multirow{2}{*}{$\begin{array}{l}\text { Name of the } \\
\text { municipality }\end{array}$} & \multirow{2}{*}{$\begin{array}{l}\text { Municipal } \\
\text { status }\end{array}$} & \multicolumn{4}{|c|}{$\begin{array}{l}\text { Revenue from the trade fair fee in } \\
\qquad 2016-2019\end{array}$} & \multicolumn{3}{|c|}{$\begin{array}{l}\text { Nominal increase/decrease in trade } \\
\text { fair fee income in PLN }\end{array}$} & \multicolumn{3}{|c|}{$\begin{array}{l}\text { Increase/decrease in the commune's } \\
\text { income from the trade fair fee in \% }\end{array}$} \\
\hline & & 2016 & 2017 & 2018 & 2019 & $2017 / 2016$ & $2018 / 2017$ & 2018/2019 & 2017/2016 & $2018 / 2017$ & $2019 / 2018$ \\
\hline Gdynia & urban & 246231 & 221724 & 217218 & 142100 & -24507 & -4506 & -75118 & $-10 \%$ & $-2 \%$ & $-35 \%$ \\
\hline Jastarnia & urban & 333107 & 367540 & 364941 & 367335 & 34433 & -2599 & 2394 & $10 \%$ & $-1 \%$ & $1 \%$ \\
\hline Łeba & urban & 449456 & 436812 & 411651 & 395519 & -12644 & -25161 & -16132 & $-3 \%$ & $-6 \%$ & $-4 \%$ \\
\hline City of Puck & urban & 177748 & 122169 & 87071 & 41604 & -55579 & -35098 & -45467 & $-31 \%$ & $-29 \%$ & $-52 \%$ \\
\hline Sopot & urban & 145258 & 146773 & 157494 & 149993 & 1515 & 10721 & -7501 & $1 \%$ & $7 \%$ & $-5 \%$ \\
\hline Miasto Ustka & urban & 255296 & 210841 & 166920 & 105618 & -44455 & -43921 & -61302 & $-17 \%$ & $-21 \%$ & $-37 \%$ \\
\hline Władysławowo & urban & 692743 & 638706 & 630924 & 787504 & -54037 & -7782 & 156580 & $-8 \%$ & $-1 \%$ & $25 \%$ \\
\hline Krokowa & rural & 162751 & 169337 & 155180 & 160429 & 6587 & -14157 & 5249 & $4 \%$ & $-8 \%$ & $3 \%$ \\
\hline Stegna & rural & 150476 & 264113 & 280977 & 297757 & 113638 & 16864 & 16780 & $76 \%$ & $6 \%$ & $6 \%$ \\
\hline $\begin{array}{l}\text { Communes of } \\
\text { Ustka }\end{array}$ & rural & 75370 & 81809 & 99923 & 112258 & 6439 & 18114 & 12335 & $9 \%$ & $22 \%$ & $12 \%$ \\
\hline
\end{tabular}

Source: Own study based on reports Rb-27s and reports on the implementation of the commune budget for 2016-2019 published in Public Information Bulletins by local governments 
Table 5: The dynamics of revenues from the trade fair fee in 2016-2019 to the budgets of the surveyed municipalities

\begin{tabular}{|c|c|c|c|c|c|c|c|c|}
\hline \multirow{2}{*}{$\begin{array}{l}\text { Name of the } \\
\text { municipality }\end{array}$} & \multirow{2}{*}{$\begin{array}{l}\text { Municipal } \\
\text { status }\end{array}$} & \multicolumn{4}{|c|}{ Revenue from the trade fair fee in $2016-2019$} & \multicolumn{3}{|c|}{$\begin{array}{l}\text { The dynamics of revenues from the } \\
\text { trade fair fee in 2016-2019 }\end{array}$} \\
\hline & & 2016 & 2017 & 2018 & 2019 & $2017 / 2016$ & 2018/2016 & $2019 / 2016$ \\
\hline Gdynia & urban & 246231 & 221724 & 217218 & 142100 & $-10 \%$ & $-12 \%$ & $-42 \%$ \\
\hline Jastarnia & urban & 333107 & 367540 & 364941 & 367335 & $10 \%$ & $10 \%$ & $10 \%$ \\
\hline teba & urban & 449456 & 436812 & 411651 & 395519 & $-3 \%$ & $-8 \%$ & $-12 \%$ \\
\hline City of Puck & urban & 177748 & 122169 & 87071 & 41604 & $-31 \%$ & $-51 \%$ & $-77 \%$ \\
\hline Sopot & urban & 145258 & 146773 & 157494 & 149993 & $1 \%$ & $8 \%$ & $3 \%$ \\
\hline Miasto Ustka & urban & 255296 & 210841 & 166920 & 105618 & $-17 \%$ & $-35 \%$ & $-59 \%$ \\
\hline Władysławowo & urban & 692743 & 638706 & 630924 & 787504 & $-8 \%$ & $-9 \%$ & $14 \%$ \\
\hline Krokowa & rural & 162751 & 169337 & 155180 & 160429 & $4 \%$ & $-5 \%$ & $-1 \%$ \\
\hline Stegna & rural & 150476 & 264113 & 280977 & 297757 & $76 \%$ & $87 \%$ & $98 \%$ \\
\hline $\begin{array}{c}\text { Communes of } \\
\text { Ustka }\end{array}$ & rural & 75370 & 81809 & 99923 & 112258 & $9 \%$ & $33 \%$ & $49 \%$ \\
\hline
\end{tabular}

Source: Own study based on reports Rb-27s and reports on the implementation of the commune budget for 2016-2019 published in Public Information Bulletins by local governments

The summary contained in Table 5 data concerning the dynamics of income from the trade fair fee in 20162019 , assuming that the base year is 2016 , indicates that out of the 10 surveyed communes, 4 recorded increases in income. The highest income growth dynamics on the trade fair fee in subsequent years compared to the base year was recorded in Stegna municipality (98\% increase in revenue to the municipality budget from the trade fair fee in 2019 compared to the base year 2016). Each year, the rural municipality of Ustka recorded an increase in revenue to the municipal budget from the trade fair fee compared to 2016, with the highest increase in 2019

Table 6: Rates of fees for trade fair fee collectors in the surveyed communes of Pomorskie Voivodeship in Poland in 2016-2019

\begin{tabular}{|c|c|c|c|c|c|c|}
\hline \multirow{2}{*}{$\begin{array}{l}\text { Name of the } \\
\text { municipality }\end{array}$} & \multirow{2}{*}{$\begin{array}{l}\text { Municipal } \\
\text { status }\end{array}$} & \multicolumn{4}{|c|}{$\begin{array}{l}\text { Rates of fees for trade fair fee collectors } \\
\qquad \text { in } 2016-2019 \text { in } \%\end{array}$} & \multirow[t]{2}{*}{ Comments } \\
\hline & & 2016 & 2017 & 2018 & 2019 & \\
\hline Gdynia & \multirow{2}{*}{ urban } & $20 \%$ & $20 \%$ & $20 \%$ & $20 \%$ & $\begin{array}{l}\text { Remuneration for the collection of fair fees at retail } \\
\text { sales stands on and off designated markets }\end{array}$ \\
\hline Gdynia & & $15 \%$ & $15 \%$ & $15 \%$ & $15 \%$ & $\begin{array}{l}\text { Remuneration for the collection of trade fair fees } \\
\text { on wholesale markets }\end{array}$ \\
\hline Jastarnia & urban & $25 \%$ & $25 \%$ & $25 \%$ & $25 \%$ & \\
\hline Łeba & urban & $10 \%$ & $10 \%$ & $10 \%$ & $10 \%$ & \\
\hline \multirow{2}{*}{ City of Puck } & \multirow{2}{*}{ urban } & $6 \%$ & $6 \%$ & $6 \%$ & $6 \%$ & $\begin{array}{l}\text { Amount of remuneration / commission in the } \\
\text { period from 01.IV. to 31.X. }\end{array}$ \\
\hline & & $10 \%$ & $10 \%$ & $10 \%$ & $10 \%$ & $\begin{array}{l}\text { Amount of commission in the period from 01.XI to } \\
\qquad 31 . I I I\end{array}$ \\
\hline Sopot & urban & $15 \%$ & $15 \%$ & $15 \%$ & $15 \%$ & \\
\hline Miasto Ustka & urban & $12 \%$ & $12 \%$ & $12 \%$ & $12 \%$ & \\
\hline Władysławowo & urban & $5 \%$ & $5 \%$ & $5 \%$ & $7 \%$ & \\
\hline Krokowa & rural & $5 \%$ & $5 \%$ & $5 \%$ & $5 \%$ & \\
\hline Stegna & rural & $20 \%$ & $20 \%$ & $20 \%$ & $20 \%$ & \\
\hline $\begin{array}{l}\text { Communes of } \\
\text { Ustka }\end{array}$ & rural & $11 \%$ & $11 \%$ & $11 \%$ & $11 \%$ & \\
\hline
\end{tabular}

Source: Own study based on the resolutions of the Municipal Councils and Commune Councils in the years 2015-2019 regarding the trade fair fee (http://edziennik.gdansk.uw.gov.pl/actbymonths) 
being $49 \%$ compared to 2016 . An interesting example of a steady annual growth rate of income from the trade fair fee is the city of Jastarnia, which annually increased its income from the trade fair fee at a level of $10 \%$ compared to the base year 2016. The highest rate of decrease in income from the trade fair fee compared to the base year was recorded by the city of Puck $(77 \%$ decrease in income from the trade fair fee in 2019 compared to 2016). The city of Puck recorded every year a high dynamics of income decrease in comparison with the base year 2016 (31\% decrease in income in 2017, 51\% decrease in income in 2018 and 77\% decrease in income in 2019). Another city affected by the high drop in revenues was the city of Ustka (59\% drop in revenues compared to the base year 2016) and Gdynia (42\% drop in revenues compared to the base year 2016).

Generally speaking, it can be seen that the dynamics of income from the trade fair fee is very different between the analysed communes.

Table 6 presents a summary of remuneration for those collecting fair fees in 2016-2019. The remuneration is expressed as a commission on the fair fees collected (percentage of the total nominal fee collected).

\section{Conclusion}

The assessment of income to the budgets of 10 selected communes from the trade fair fee indicates that in 2016-2019 it represented a small percentage share in total income. Maximum share of the trade fair fee in the total revenue to the budgets of municipalities was $1.60 \%$ (Łeba in 2016) and the lowest share of the exhibition fee in the total income of the commune was $0.01 \%$ (in Gdynia in 2018-2019). Moreover, the results of the analysis indicate a dynamic annual decrease in the nominal total income from the fair fee (in particular years) in 3 municipalities (Gdynia, Łeba, Ustka). The highest - 52\% decrease in revenue from the exhibition fee on an annual basis was observed in Puck in 2019 as compared to 2018. Moreover, a general downward trend in revenue from the exhibition fee to the budgets of the analysed communes was noticed.

The small share of the fair fee in the municipalities' income and the decreasing nominal income from this tribute may be a justification for the individual municipalities to decide to liquidate it. Additionally, it should be emphasized that charging the exhibition fee generates significant costs due to the amount of the fee paid to persons for performing these collection activities for a given commune. The assessed communes paid the collectors a commission ranging from $5 \%$ to $25 \%$ of the amount of fees collected from marketplace vendors. Charging a fee from persons selling goods at marketplaces in addition to the low income to the budget limits to a certain extent, the freedom to exchange goods at marketplaces in the municipality. This is due to the fact that buyers have to bear the additional cost of selling the offered goods on a daily basis without receiving an actual public service from the municipality. A possible decision by the local authorities to waive the fair fee on their territory may improve the image of the commune in question and at the same time cause little loss to the commune budget. However, such a decision by the municipality should be preceded by financial analyses of the municipality budget.

In general, it should be noted that the studies carried out show that a decision by the public authorities to abolish the trade fair fee would not have the effect of reducing revenue to the commune's budget. On the contrary, it could be a factor in improving local trade development in the municipality.

\section{REFERENCES}

Bahl, R., Linn, J. (1992). Urban Public Finance in Developing Countries. New York: Oxford University Press, The World Bank, Washington. Retrieved from: http://documents.worldbank.org/curated/en/963911468739534803/pdf/multipage.pdf

Bird, R.M. (2010). Subnational Taxation in Developing Countries: A Review of the Literature. Policy Research Working Paper, Washington DC: The World Bank.

Copley, P.A. (1991). The Association between Municipal Disclosure Practices and audit quality. Journal of Accounting and Public Policy, Volume 10, Issue 4, Winter 1991, 245-266. 
Freire, M.E., Garzón, H. (2014). Managing Local Revenues. In Farvacque-Vitkovic, C., Kopanyi, M. (eds.) Municipal Finances. A Handbook for Local Governments (pp. 147-213). Washington DC: International Bank for Reconstruction and Development, The World Bank.

Kwaśniewski, R., Wantoch-Rekowski, (2019). The Right of Municipalities to Differentiate Market Charge Rates as an IImplementation of the Local Tax Policy in Poland. Prawo Budżetowe Państwa i Samorządu, Vol 7, No 1 (pp. 67-85). Nicolaus Copernicus University in Toruń.

Owsiak, S. (2002). Finanse publiczne. Teoria i praktyka. Warsaw: PWN.

Maciejewski, G. (2017). Formaty handlu detalicznego w Polsce w ocenie konsumentów, Studia Ekonomiczne. Scientific Journals of the University of Economics in Katowice, No. 316 (pp. 136-146). Retrieved from: https://www.researchgate. net/profile/Grzegorz_Maciejewski2/publication/319448830_Formaty_handlu_detalicznego_w_Polsce_w_ocenie_ konsumentow_Retailing_formats_in_Poland_in_consumers'_opinion/links/59aac08da6fdcce55a34bbdf/Formatyhandlu-detalicznego-w-Polsce-w-ocenie-konsumentow-Retailing-formats-in-Poland-in-consumers-opinion.pdf

Parlińska, A. (2010). Parapodatkowe instrumenty finansowe. Podstawka, M. (Ed.). Finanse. Instytucje, Instrumenty, Podmioty, Rynki, Regulacje. Warsaw: PWN, Warsaw 2010, (pp. 350-353).

Podstawka, M. (2011). Podstawy finansów. Teoria i praktyka. Warsaw: Warsaw University of Life Sciences (WULS SGGW).

Spencer Pickett, K.H. (2010). The Internal Auditing Handbook. (3rd ed.), West Sussex, United Kingdom: John Wiley \& Sons Ltd.

Stiglitz, J.E., Rosengard, Jay K. (2015). Economics of the Public Sector (4rd ed.). New York, London: W.W. Norton Company.

Taxation Trends in the European Union. Data for The EU member states, Iceland and Norway. 2019 edition, (2019). Luxembourg: Publications Office of the European Union. Retrieved from: https://ec.europa.eu/taxation_customs/ sites/taxation/files/taxation_trends_report_2019.pdf

World Economic Outlook Reports, April 2020: Chapter 1. Retrieved from: https://www.imf.org/en/Publications/WEO/ Issues/2020/04/14/weo-april-2020

Consumer Price Index - March 2020 in USA, U.S. Bureau of Labor Statistics. Retrieved from: https://www.bls.gov/news. release/pdf/cpi.pdf

Yearly price indices of consumer goods and services in years 2016-2019 in Poland. Retrieved from https://stat.gov.pl/ en/topics/prices-trade/price-indices/price-indices-of-consumer-goods-and-services/yearly-price-indices-ofconsumer-goods-and-services-from-1950/

Act of 13 November 2003 on the income of local government units (i.e. Journal of Laws of 2020, item 23).

The Act of 12 January 1991 on local taxes and fees (i.e., Journal of Laws of 2019, item 1170).

Announcements of the Minister of Finance and the Minister of Finance and Development on the upper limits of specific taxes and local fees in the years 2016, 2017, 2018, 2019 (M.P. from 2015, item 735, M.P. from 2016, item 779, M.P. form 2017, p item 800, M.P. from 2018 item 745).

Resolution of the Gdańsk City Council XV/398/15 of 29 October 2015 repealing Resolution No. LVIII/1396/14 of the Gdańsk City Council of 30 October 2014 on the fair fee.

Resolution No. XIII/250/15 of the Gdynia City Council of 28 October 2015 on defining the principles of determining and collecting the fair fee in the City of Gdynia, as well as its amount (Journal of Laws of the Pomeranian Voivodeship from 2015, item 3588).

Resolutions of the Gdynia City Council on the fair fee for the years 2016-2019. Retrieved from: https://bip.um.gdynia.pl/podatki-i-oplaty-lokalne-w-2016-roku,448/oplata-targowa-w-2016-roku,443138 https://bip.um.gdynia.pl/podatki-i-oplaty-lokalne-w-2017-roku,6288/oplata-targowa-w-2017-roku,459663 https://bip.um.gdynia.pl/podatki-i-oplaty-loklane-w-2018-roku,7472/oplata-targowa-w-2018-roku,516069 https://bip.um.gdynia.pl/podatki-i-oplaty-lokalne-w-2019-roku,7977/oplata-targowa-w-2019-roku,532055

Resolutions of the individual communes covered by the analysis on fair fee cases in 2016-2019 published in Official Journals of Pomorskie Voivodeship in 2015-2019. Retrieved from: http://edziennik.gdansk.uw.gov.pl/actbymonths Report on the implementation of the Gdynia budget for 2016-2019. Retrieved from: 
https://bip.um.gdynia.pl/2016,336/sprawozdanie-z-wykonania-budzetu-miasta-gdyni-za-2016-rok,482556 https://bip.um.gdynia.pl/2017-3,6283/sprawozdanie-z-wykonania-budzetu-miasta-gdyni-za-2017-rok,519667 https://bip.um.gdynia.pl/2018-2,7389/sprawozdanie-z-wykonania-budzetu-miasta-gdyni-za-2018-rok,535901 https://bip.um.gdynia.pl/2019,7972/sprawozdanie-z-wykonania-budzetu-miasta-gdyni-za-2019-rok,548196 Report on the implementation of Jastarnia's budget for 2016-2019. Retrieved from:

http://bip.jastarnia.pl/dokumenty/4913

http://bip.jastarnia.pl/dokumenty/5508

http://bip.jastarnia.pl/dokumenty/6401

http://bip.jastarnia.pl/dokumenty/7266

Report on the implementation of the Łeba budget for 2016-2019. Retrieved from: https://prawomiejscowe.pl/GminaMiejskaLeba/document/616721/Zarz\%C4\%85dzenie-38_2020 https://prawomiejscowe.pl/GminaMiejskaLeba/document/543727/Zarz\%C4\%85dzenie-45_2019 https://prawomiejscowe.pl/GminaMiejskaLeba/document/482486/Zarz\%C4\%85dzenie-56_2018 https://prawomiejscowe.pl/GminaMiejskaLeba/document/405097/Uchwa\%C5\%82a-XXIX_348_2017

Report on the implementation of the budget of Krokowa commune for the years 2016-2019. Retrieved from: http://bip.krokowa.pl/dokumenty/3961 http://bip.krokowa.pl/dokumenty/3978 http://bip.krokowa.pl/dokumenty/4729 http://bip.krokowa.pl/dokumenty/5456

Report on the implementation of the Puck City budget for 2016-2019. Retrieved from:: http://bip.miastopuck.pl/dokumenty/3195 http://bip.miastopuck.pl/dokumenty/4237 http://bip.miastopuck.pl/dokumenty/5259 http://bip.miastopuck.pl/dokumenty/6029

Report on the implementation of the Sopot budget for 2016-2019. Retrieved from: https://www.bip.sopot.pl/a,17340,budzet-sopotu-2016.html https://www.bip.sopot.pl/a,17755,budzet-sopotu-2017.html https://www.bip.sopot.pl/a,18346,budzet-sopotu-2018.html https://www.bip.sopot.pl/a,18881,budzet-sopotu-2019.html

Report on the implementation of the budget of Stegna Municipality for 2016-2019. Retrieved from: http://bip.stegna.pl/system/obj/2343_51_2017._Zarzadzenie.WYKONANIE_ZA_2016_do_wyslania.Kopia.pdf http://bip.stegna.pl/system/obj/4562_49_2018_Zarzadzenie.WYKONANIE_ZA_2017.pdf http://bip.stegna.pl/system/obj/7187_50_2019_Zarzadzenie_Sprawozdanie_opisowe.pdf http://bip.stegna.pl/system/obj/8062_50_2020_zarz..pdf

Report on the implementation of the budget of the City of Ustka for 2016-2019. Retrieved from: https://bip.um.ustka.pl/a,28484,iv-kwartal-2019.html https://bip.um.ustka.pl/a,27349,iv-kwartal-2018-rok.html https://bip.um.ustka.pl/a,26411,iv-kwartal-2017-rok.html https://bip.um.ustka.pl/a,24903,iv-kwartal-2016-rok.html

Report on the implementation of the budget of the commune of Ustka for the years 2016-2019. Retrieved from: http://bip.ustka.ug.gov.pl/a,24111,sprawozdania-budzetowe-za-iv-kwartal-2016.html http://bip.ustka.ug.gov.pl/a,24780,zarzadzenie-nr-00505242018-wojta-gminy-ustka-z-dnia-26-marca-2018-roku-wsprawie-przedstawienia-spra.html http://bip.ustka.ug.gov.pl/a,26038,zarzadzenie-nr-0050712019-wojta-gminy-ustka-z-dnia-20-marca-2019-roku-wsprawie-przedstawienia-spraw.html

Report on the implementation of the budget of Władysławowo City for 2016-2019. Retrieved from: https://bip.wladyslawowo.pl/a,22492,rb-27s-sprawozdanie-z-wykonania-planu-dochodow-budzetowych-jednostkisamorzadu-terytorialnego-okres-.html 
https://bip.wladyslawowo.pl/a,24250,rb-27s-sprawozdanie-z-wykonania-planu-dochodow-budzetowych-jednostkisamorzadu-terytorialnego-okres-.html

https://bip.wladyslawowo.pl/a,25915,rb-27s-sprawozdanie-z-wykonania-planu-dochodow-budzetowych-jednostkisamorzadu-terytorialnego-od-poc.html

https://bip.wladyslawowo.pl/a,27289,rb-27s-sprawozdanie-z-wykonania-planu-dochodow-budzetowych-jednostkisamorzadu-terytorialnego-od-poc.html

http://bip.ustka.ug.gov.pl/a,27137,sprawozdania-za-iv-kwartal.html 